\title{
Kinetics and thermodynamic studies for removal of acid blue 129 from aqueous solution by almond shell
}

\author{
Mohammad Reza Fat'hi ${ }^{*}$, Arash Asfaram², Anahita Hadipour ${ }^{3}$ and Mostafa Roosta ${ }^{4}$
}

\begin{abstract}
Efficiency and performance of Almond shell (AS) adsorbent for the removal and recovery of Acid Blue 129 (AB129) from wastewater is presented in this report. The influence of variables including $\mathrm{pH}$, initial dye concentration, adsorbent dosage, particle size, contact time and temperature on the dye removal have been investigated in batch method by one at a time optimization method. The experimental equilibrium data were tested by four widely used isotherm models namely, Langmuir, Freundlich, Tempkin and Dubinin-Radushkevich (D-R). It was found that adsorption of AB129 on AS well with the Langmuir isotherm model, implying monolayer coverage of dye molecules onto the surface of the adsorbent. More than $98 \%$ removal efficiency was obtained within 14 min at adsorbent dose of $0.4 \mathrm{~g}$ for initial dye concentration of $40 \mathrm{mg} / \mathrm{L}$ at $\mathrm{pH}$ 2. Kinetics of the adsorption process was tested by pseudo-first-order and pseudo-second-order kinetics, and intraparticle diffusion mechanism. Pseudo-second-order kinetic model provided a better correlation for the experimental data studied in comparison to the pseudo-first-order model. Calculation of various thermodynamic parameters such as, Gibb's free energy, entropy and enthalpy of the on-going adsorption process indicate feasibility and endothermic nature of AB129 adsorption on all adsorbents. This work can be used in design of adsorption columns for dyes removal.
\end{abstract}

Keywords: Acid blue 129, Almond shell, Equilibrium studies, Kinetics, Thermodynamics

\section{Introduction}

Textile industry uses large volumes of water in wet processing operations and thereby, generates large amounts of dissolved dyestuffs and other products such as dispersing agents, dye bath carriers, salts, emulsifiers, leveling agents and heavy metals [1]. Colored dyes are not only aesthetic, carcinogenic but also hinder light penetration and disturb life processes of living organisms in water. Acid Blue 129 (AB129), an acidic dye, is most widely used for the dyeing of cotton, wool, silk, nylon, paper and leather (Table 1). This dye may be harmful if contact to eyes, respiratory system and skin. Therefore, the removal of such colored agents from aqueous effluents is necessary [2].

Traditionally, well known protocols such as coagulation, nano filtration and ozonalysis, membrane filtration,

\footnotetext{
* Correspondence: fathiemadabadi@yahoo.com

'Department of Chemistry, College of Science, Shahid Chamran University, P.O. Box: 6135743337, Ahvaz, Iran

Full list of author information is available at the end of the article
}

oxidation and adsorption process are applied to remove color and other contaminations from aqueous media [3-7]. Adsorption is most popular technique that benefit from advantages such as high efficiency and ability to use generable non-toxic and cheap adsorbents [8-22]. Although, activated carbon appears to be the widely used techniques for dye removal, but in view of the high cost and regeneration problems scope of many adsorption studies has been focused to derive cheaper adsorbents from the waste materials [23]. During the past decades, several researches are to utilize low cost and easily available natural materials as potential adsorbents for removal of dyes [24-29]. The present work aims to study a convenient and economic method for AB129 removal from water by adsorption on AS as low cost and abundantly available adsorbent. The effects of initial AB129 concentration, contact time, $\mathrm{pH}$, particle size and amount of adsorbent on AB129 removal have been evaluated.

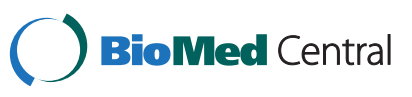

(c) 2014 Fat'hi et al.; licensee BioMed Central Ltd. This is an Open Access article distributed under the terms of the Creative Commons Attribution License (http://creativecommons.org/licenses/by/2.0), which permits unrestricted use, distribution, and reproduction in any medium, provided the original work is properly credited. 
Table 1 Properties of the acid blue 129

\begin{tabular}{cc}
\hline C.I. number & Acid blue 129 \\
\hline Chemical formula & $\mathrm{C}_{23} \mathrm{H}_{19} \mathrm{~N}_{2} \mathrm{NaO}_{5} \mathrm{~S}$ \\
Molecular weight & 458.46 \\
Name & $\begin{array}{c}\text { Sodiume-1-amino-4-(2, 4, 6-trimethylanilino) } \\
\text { anthraquinone-2-sulfonate. }\end{array}$ \\
Maximum wavelength (nm) & 600 \\
\hline
\end{tabular}

\section{Materials and methods}

\section{Chemicals and instruments}

AS were supplied from the Arctic Sea Region of Iran. They were firstly dried, crushed in a ball mill and sieved to obtain a particle size between $0-177,210-297$ and $350-500 \mu \mathrm{m}$. All chemical used were of analytical grade and doubled distilled water was used throughout. A stock solution of $200 \mathrm{mg} / \mathrm{L}$ of $\mathrm{AB} 129$ was prepared by dissolving $0.100 \mathrm{~g}$ of solid dye in water and diluting to $500 \mathrm{~mL}$ in a volumetric flask. The AB129 concentration evaluation was carried out using Shimadzu UV-vis spectrophotometer model 160A (Shimadzu, Japan) at a wavelength of $600 \mathrm{~nm}$. The $\mathrm{pH}$ measurements were carried out using $\mathrm{pH} /$ Ion meter model 691 (Metrohm, Switzerland, Swiss).

\section{Method}

To study the effect of important parameters like the $\mathrm{pH}$, adsorbent dosage, contact time, initial dye concentration and temperature on the adsorptive removal of AB129 batch experiments were conducted. For each experimental run, $25 \mathrm{~mL}$ of AB129 solution of known concentration, $\mathrm{pH}$ and amount of the adsorbent were taken in a $50 \mathrm{ml}$ Erlenmeyer flask with middle magnet. This mixture was agitated on stirrer at a constant speed in a temperature controlled. Samples were withdrawn at different time intervals (0-15 min for AS) and kinetics, thermodynamic, isotherm and other parameters of adsorption was determined by analyzing of remaining dye concentration from aqueous solution.

Experiments were carried out at $\mathrm{pH}=2.0$ that the initial $\mathrm{pH}$ of the solution was adjusted by addition of aqueous solutions of $\mathrm{HCl}$ or $\mathrm{NaOH}$.

For adsorption isotherms, dye solutions of different concentrations $(10-90 \mathrm{mg} / \mathrm{L})$ and at temperatures $\left(25^{\circ} \mathrm{C}\right)$ were agitated with known amounts of adsorbents until the equilibrium was achieved.

\section{Results and discussion}

Solution $\mathrm{pH}$ affects both aqueous chemistry and surface binding sites of the adsorbents. The effect of initial $\mathrm{pH}$ on adsorption of $\mathrm{AB} 129$ was studied from $\mathrm{pH} 2$ to 12 at $25^{\circ} \mathrm{C}$, initial dye concentration of $40 \mathrm{mg} / \mathrm{L}$, adsorbent dosage of $0.4 \mathrm{~g}$ and contact time of $10 \mathrm{~min}$. The maximum adsorption of the $\mathrm{AB} 129$ is obtained at $\mathrm{pH}=2$ (Figure 1). The acidity constant value of the most acidic group of the AB 129 molecule is 1.6. This functional group can be easily dissociated and thus, the $A B 129$ molecule has net negative charges in the working experimental conditions [30,31].

At acidic $\mathrm{pH}$ the $\mathrm{H}^{+}$ion concentration in the system increased and the surface of the AS acquires positive charge by absorbing $\mathrm{H}^{+}$ions. As the $\mathrm{pH}$ of the system increases, the number of negatively charged sites increases and the number of positively charged sites decreases. Negatively charged surface sites on the AS do not favor the adsorption of AB129 anions due to the electrostatic repulsion. Also lower adsorption of AB129 at alkaline $\mathrm{pH}$ is due to the presence of excess $\mathrm{OH}^{-}$ions, which destabilize anionic AB129 and compete with the AB129 anions for the adsorption sites. The most effective $\mathrm{pH}$ was 2.0 and it was used in further studies.

The particle size distribution of AS determined by sieving the samples manually shaking with stainless steel mesh screens of standard (international ASTM with meshes 40, 60 and 100). For batch adsorption experiments, three different particle sizes viz. 40 and $60-100$ AS mesh were selected and difference in the amount adsorbed was noticed by using different mesh sizes. Effect of sieve size of adsorbent on the adsorption was studied at $25^{\circ} \mathrm{C}, 0.4 \mathrm{~g}$ of $\mathrm{AS}, \mathrm{pH}=2$ and $40 \mathrm{mg} / \mathrm{L}$ of $\mathrm{AB} 129$. It was observed that adsorption was found to increase with the 60-100 mesh sizes in Figure 2. This is due to increase in the surface area of the adsorbent and accessibility of the adsorbent pores towards the AB129 [32].

Figure 3 demonstrates the effect of adsorbent dosages for removal of the AB129 from aqueous solution. It was observed that highest amount of AB129 removal was attained for adsorbent mass of at least adsorbent.

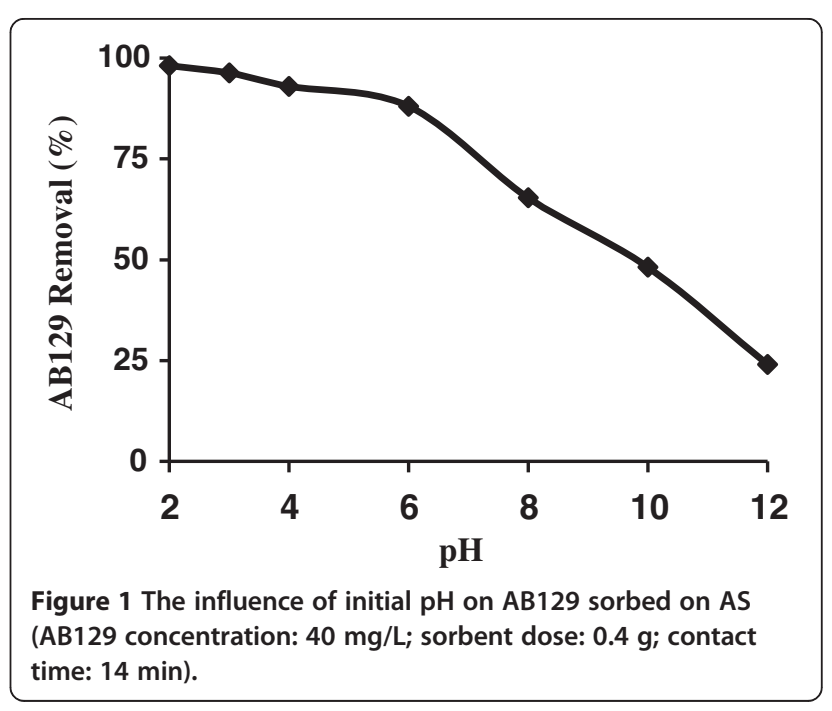




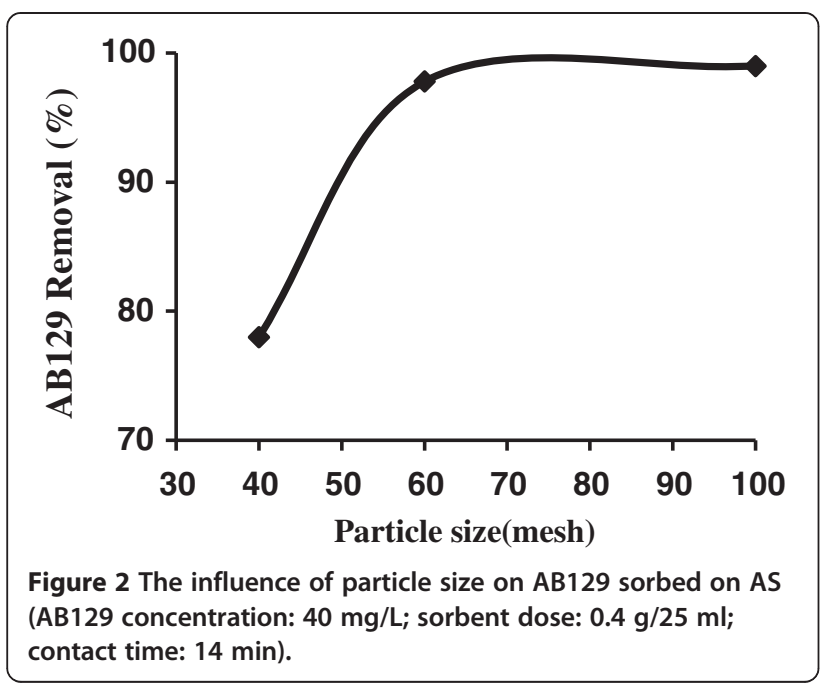

For adsorbent dosage higher than $0.4 \mathrm{~g}$ the AB129 removal remained almost constant. Increases in the percentage of AB129 removal with adsorbent dosage could be attributed to increases in the adsorbent surface areas, augmenting its number of adsorption sites available for adsorption [33,34]. In order to continue this work, the adsorbent dosage was fixed at $0.4 \mathrm{~g}$, since this adsorbent dosage correspond to the minimum amount of adsorbent which lead to a constant and maximum removal of AB129.

Studies for investigation of the effect of dye concentration on its removal carried out by adding of $0.4 \mathrm{~g}$ prepared AS in $25 \mathrm{~mL}$ of solution at different concentration of $10-70 \mathrm{mg} / \mathrm{L}, \mathrm{pH}=2$ and room temperature $\left(25^{\circ} \mathrm{C}\right)$. As shown in Figure 4, by increasing of initial dye concentration, removal of dye was decreased.

The adsorption rate, obtained for AB129 adsorption on AS was observed by decrease of the concentration of

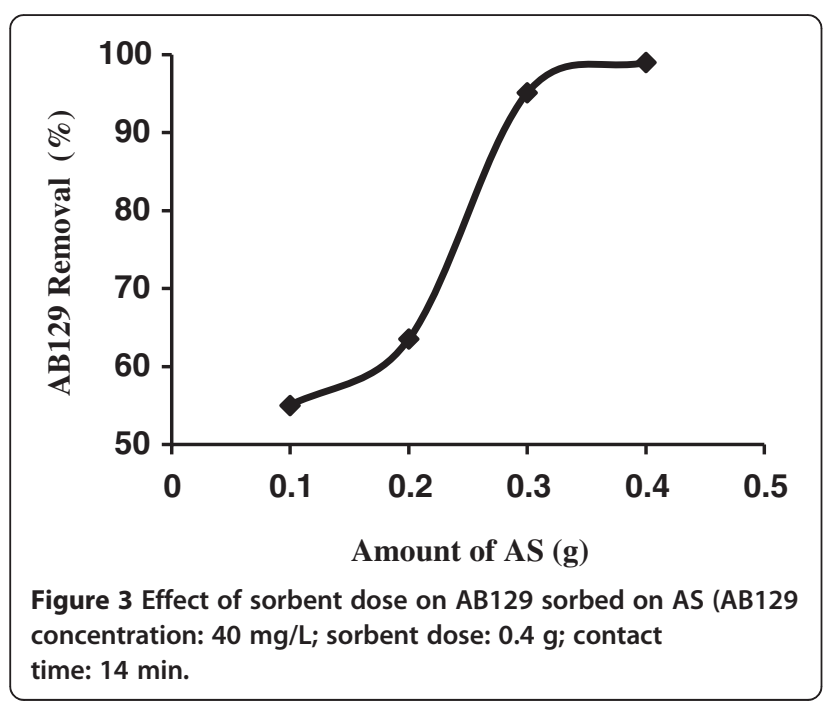

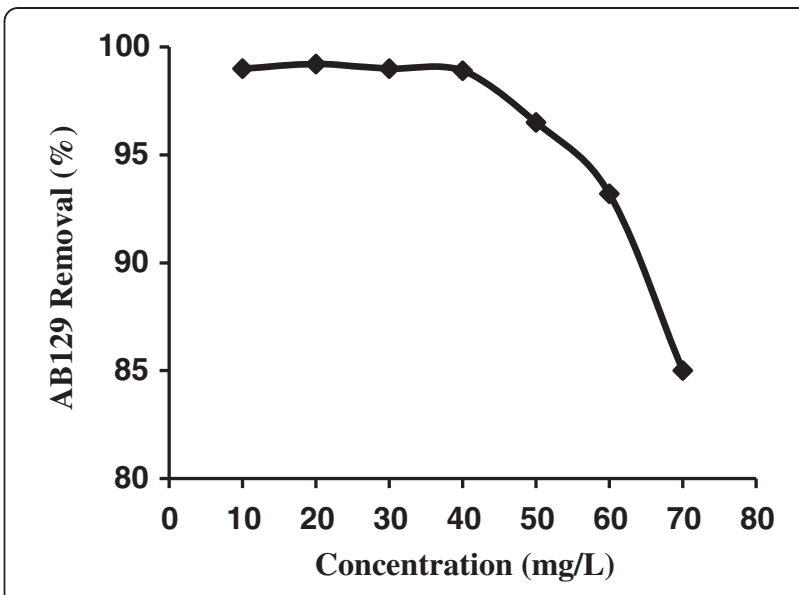

Figure 4 The effect of AB129 concentration on sorbed on AS (sorbent dose: $0.4 \mathrm{~g} / 25 \mathrm{~mL}$; contact time: $14 \mathrm{~min}$ ).

AB129 within the adsorption medium with contact time. As shown in Figure 5, it can be concluded that maximum dye removal could be achieved when the sonication time was above $14 \mathrm{~min}$. After equilibrium, the amount of adsorbed dye did not change significantly with time.

At $40 \mathrm{mg} / \mathrm{L}$ of $\mathrm{AB} 129$, the removal rate in the first varies from $58.5 \%$ to $94.24 \%$ of the maximum removal onto AS. For instance, the adsorbents exhibited three stages, which can be attributed to each linear portion of the figure. The first linear portion was attributed to the diffusion process of AB129 to the adsorbent surfaces $[35,36]$, hence, was the fastest adsorption stage.

This result is corroborated by the factionary-order kinetic model. The second linear portion was attributed to intra-particle diffusion, which was delayed process. The third stage may be regarded as the diffusion through smaller pores, which is followed by the establishment of equilibrium. The surface of AS may contain a large number of active sites and the solute adsorption can be related

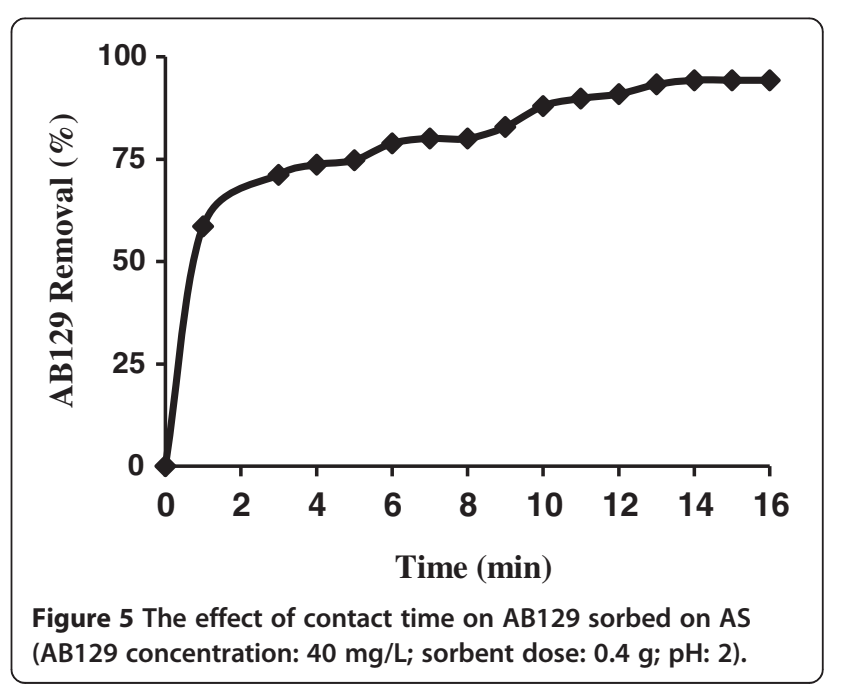


to the active sites on equilibrium time. Also up to $90 \%$ of the total amount of AB129 adsorption was found to occur in the first rapid phase $(10 \mathrm{~min})$ and thereafter the adsorption rate was found to decrease. The higher adsorption rate at the initial period (first $10 \mathrm{~min}$ ) may be due to too number of vacant sites available at the initial stage. As a result there exist too concentration gradients between adsorbate in solution and onto adsorbent surface. This increased in concentration gradients tends to increase in AB129 adsorption at the initial stages.

\section{Adsorption kinetic studies}

The mechanism of adsorption was investigated by pseudo first order and pseudo second order models.

Based on the pseudo first-order expression (Lagergren model) by plotting the values of $\log \left(q_{e}-q_{t}\right)$ against $t$ give a linear relationship that $q_{e}$ and $k_{1}$ values can be determined from the intercept and slope of the obtained line, respectively (Figure 6 and Table 2). The parameters qe and qt are amounts of dye adsorbed ( $\mathrm{mg} / \mathrm{g}$ ) on adsorbent at equilibrium and at time $t$, respectively and $k 1$ is rate constant of pseudo first order adsorption $(1 / \mathrm{min})$.

Figure 6 was used to determine pseudo first order rate constant $(\mathrm{k} 1)$ and theoretical amount of dye adsorbed per unit mass of adsorbent qe(the). Distance of qe(the) from qe(exp) value indicate that this model was not fit well with the experimental data (Table 2) [37].

The plot of $t / q_{t}$ versus $t$ for the pseudo-second-order kinetic model gives a straight line that $k_{2}$ and equilibrium adsorption capacity $\left(q_{e}\right)$ were calculated from the intercept and slope of this line, respectively (Figure 7). Where $\mathrm{k} 2$ is rate constant of second order adsorption (g/(mg min)). The high value of $\mathrm{R}^{2}(0.994)$ and closeness of experimental and theoretical adsorption capacity (qe) value show the applicability of this model to explain the experimental data (Table 2).

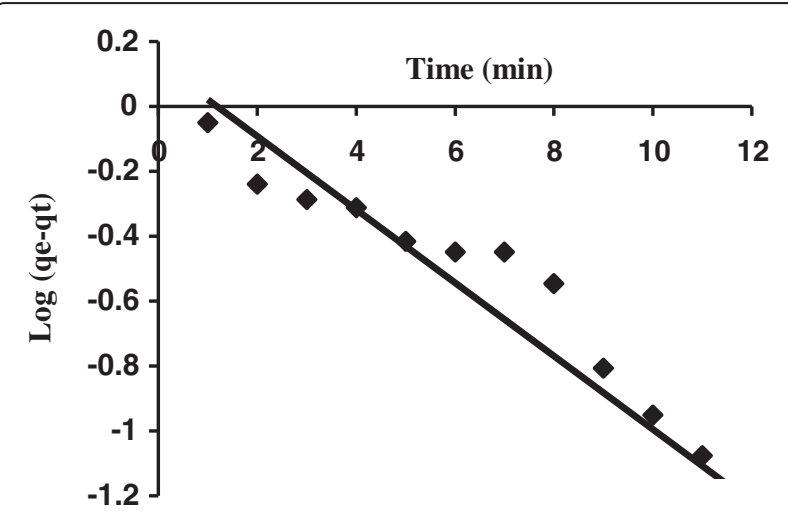

Figure 6 Pseudo-first-order kinetic model plot for the adsorption on AS (AB129 concentration: $40 \mathrm{mg} / \mathrm{L}$; sorbent dose: $0.4 \mathrm{~g} / 25 \mathrm{~mL}$; contact time: $14 \mathrm{~min}$ ).
Table 2 Kinetic parameters for the adsorption of $\mathbf{4 0} \mathbf{~ m g} / \mathbf{L}$ AB129 onto AS

\begin{tabular}{|c|c|c|c|}
\hline Model & Equation & Parameters & Value \\
\hline \multirow{4}{*}{$\begin{array}{l}\text { Pseudo-first- } \\
\text { order kinetic }\end{array}$} & \multirow{4}{*}{$\begin{array}{l}\log \left(q_{e}-q_{t}\right)=\log \left(q_{e}\right)- \\
k_{1} / 2.303 t\end{array}$} & $\mathrm{k}_{1}(1 / \mathrm{min})$ & 0.210 \\
\hline & & $\mathrm{q}_{\mathrm{e}}(\mathrm{calc})(\mathrm{mg} / \mathrm{g})$ & 1.096 \\
\hline & & $R^{2}$ & 0.912 \\
\hline & & $\mathrm{k}_{2}(\mathrm{~g} /(\mathrm{mg} \min ))$ & 0.313 \\
\hline \multirow{4}{*}{$\begin{array}{l}\text { Pseudo-second- } \\
\text { order kinetic }\end{array}$} & \multirow{4}{*}{$\left(t / q_{t}\right)=1 /\left(k_{2} q_{e}^{2}\right)+1 / q_{e}(t)$} & $\mathrm{q}_{\mathrm{e}}(\mathrm{calc})(\mathrm{mg} / \mathrm{g})$ & 2.532 \\
\hline & & $\mathrm{R}^{2}$ & 0.994 \\
\hline & & $\mathrm{H}(\mathrm{mg} /(\mathrm{g} \min ))$ & 1.731 \\
\hline & & $\begin{array}{l}\mathrm{K}_{\text {diff }}(\mathrm{mg} / \\
\left.\left(\mathrm{g} \min ^{1 / 2}\right)\right)\end{array}$ & 0.519 \\
\hline \multirow{3}{*}{$\begin{array}{l}\text { Intraparticle } \\
\text { diffusion }\end{array}$} & \multirow[t]{3}{*}{$\mathrm{q}_{\mathrm{t}}=\mathrm{K}_{\mathrm{dif}} \mathrm{t}^{1 / 2}+\mathrm{C}$} & $C(\mathrm{mg} / \mathrm{g})$ & 1.221 \\
\hline & & $R^{2}$ & 0.949 \\
\hline & & $\beta(\mathrm{g} / \mathrm{mg})$ & 3.068 \\
\hline \multirow[t]{3}{*}{ Elovich } & \multirow[t]{3}{*}{$q_{t}=1 / \beta \ln (a \beta)+1 / \beta \ln (t)$} & $a(m g /(g \min ))$ & 10.21 \\
\hline & & $R^{2}$ & 0.973 \\
\hline & & $q_{e}(\exp )(m g / g)$ & 2.356 \\
\hline
\end{tabular}

\section{Adsorption equilibrium study}

Adsorption isotherms are prerequisites to understand the nature of the interaction between adsorbate and the adsorbent used for the removal of organic pollutants $[38,39]$. The equation parameters of various adsorption isotherm equations such as Langmuir, Freundlich, Temkin, Dubinin-Radushkevich (D-R) and HarkinsJura isotherms provide some insight into the adsorption mechanism, the surface properties and affinity of the adsorbent for adsorbate $[40,41]$.

The Langmuir isotherm is based on the assumption that the adsorption process takes place at specific homogeneous sites within the adsorbent surface and that once a dye molecule occupies a site, no further adsorption

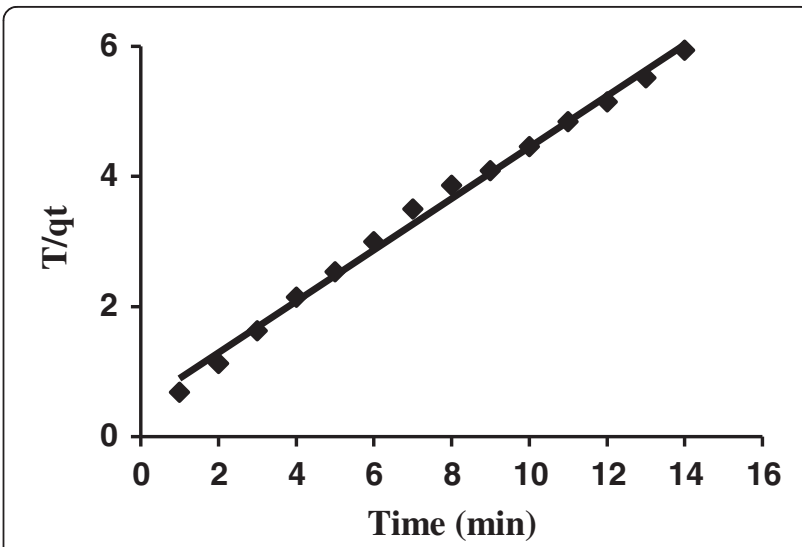

Figure 7 Pseudo-second-order kinetic model plot (AB129 concentration: $40 \mathrm{mg} / \mathrm{L}$; sorbent dose: $0.4 \mathrm{~g} / 25 \mathrm{~mL}$; contact time: $14 \mathrm{~min}$ ). 
can take place at that site, which concluded that the adsorption process is monolayer in nature.

Langmuir isotherm is based on the assumption that:

a) Maximum adsorption corresponds to a saturated monolayer of adsorbate molecules on the adsorbate surface.

b) The energy of the adsorption is constant.

c) There is no transmigration of adsorbate molecules in the plane of adsorbent surface [42]. Based on the linear form of Langmuir isotherm model (according to Table 3), the values of $K_{a}$ (the Langmuir adsorption constant $(\mathrm{L} / \mathrm{mg})$ ) and $Q_{m}$ (theoretical maximum adsorption capacity $(\mathrm{mg} / \mathrm{g})$ ) were obtained from the intercept and slope of the plot of $\mathrm{C}_{\mathrm{e}} / \mathrm{q}_{\mathrm{e}}$ vs $\mathrm{C}_{\mathrm{e}}$, respectively (Figure 8). The values of $\mathrm{Qm}$ and $K_{a}$ are $11.95 \mathrm{~m} / \mathrm{g}$ and $0.902 \mathrm{~L} / \mathrm{mg}$, respectively shown in Table 3. The high correlation coefficient (0.994) shows the applicability of Langmuir model for interpretation of the experimental data.

The data was analyzed by the linearized form of Freundlich isotherm model. In this model, $\mathrm{q}_{\mathrm{e}}$ is the amount of adsorption, $\mathrm{kf}$ is the Freundlich constant related to sorption capacity and $1 / \mathrm{n}$ is a constant related to energy or intensity of adsorption. This gives an expression encompassing the surface heterogeneity and the exponential distribution of activated sites and their energies. This isotherm dose not predicts any saturation of the adsorbent surface. The Freundlich exponents $\mathrm{k}_{\mathrm{F}}$ and $1 / \mathrm{n}$ can be determined from the linear plot of log qe $v s . \log$ Ce is shown in Table 3. The values of the Freundlich constants $K_{F}$ and $1 / \mathrm{n}$ are 0.508 respectively shown in Table 3 . The slope $1 / \mathrm{n}$ ranging between 0 and 1 is a measure of adsorption

Table 3 Isotherm constant parameters and correlation coefficients calculated for the adsorption of AB129 onto AS

\begin{tabular}{|c|c|c|c|}
\hline Isotherm & Equation & Parameters & Value \\
\hline & & Qm (mg/g) & 11.95 \\
\hline \multirow[t]{3}{*}{ Langmuir } & \multirow[t]{3}{*}{$1 / \mathrm{q}_{\mathrm{e}}=1 /\left(\mathrm{K}_{\mathrm{a}} \mathrm{Q}_{\mathrm{m}} \mathrm{C}_{\mathrm{e}}\right)+1 / \mathrm{Q}_{\mathrm{m}}$} & $\mathrm{Ka}(\mathrm{L} / \mathrm{mg})$ & 0.902 \\
\hline & & R2 & 0.994 \\
\hline & & $1 / \mathrm{n}$ & 0.508 \\
\hline \multirow[t]{3}{*}{ Freundlich } & \multirow[t]{3}{*}{$\ln q_{e}=\ln K_{F}+(1 / n) \ln C_{e}$} & $\mathrm{KF}(\mathrm{L} / \mathrm{mg})$ & 4.779 \\
\hline & & R2 & 0.929 \\
\hline & & B1 & 2.373 \\
\hline \multirow[t]{3}{*}{ Tempkin } & \multirow[t]{3}{*}{$\mathrm{q}_{e}=\mathrm{B}_{1} \ln \mathrm{K}_{\mathrm{T}}+\mathrm{B}_{1} \ln C_{\mathrm{e}}$} & $\mathrm{KT}(\mathrm{L} / \mathrm{mg})$ & 11.35 \\
\hline & & R2 & 0.993 \\
\hline & & Qs (mg/g) & 8.207 \\
\hline \multirow{3}{*}{$\begin{array}{l}\text { Dubinin- } \\
\text { Radushkevich }\end{array}$} & \multirow{3}{*}{$\ln q_{e}=\ln Q_{s}-B \varepsilon^{2}$} & $B \times 10-5$ & 0.8 \\
\hline & & E & 250 \\
\hline & & R2 & 0.948 \\
\hline
\end{tabular}

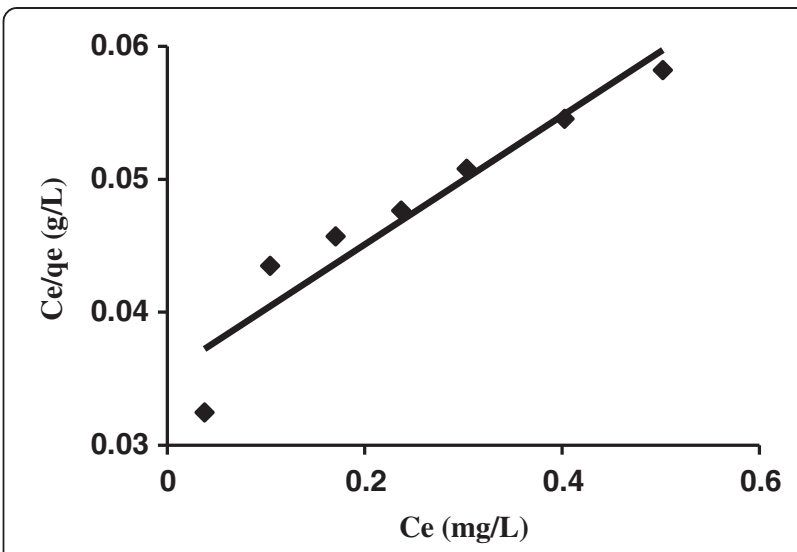

Figure 8 Langmuir isotherm models plot for the adsorption on AS (AB129 concentration: $10-90 \mathrm{mg} / \mathrm{L}$; sorbent dose: $0.4 \mathrm{~g} /$ $25 \mathrm{ml}$; contact time: $14 \mathrm{~min}$ ).

intensity or surface heterogeneous, becoming more heterogeneous as its value gets closer to zero [43].

Heat of adsorption and the adsorbent-adsorbate interaction on adsorption isotherms were studied by Tempkin [44]. The constants obtained for Tempkin isotherm are shown in Table 3. The linear form of DubininRadushkevich isotherm equation was applied to estimate the porosity apparent free energy and the characteristic of adsorption [45]. The constant obtained for D-R isotherms are shown in Table 3. The mean adsorption energy $(E)$ gives information about chemical and physical nature of adsorption.

As seen from Table 3, the Langmuir model yields a somewhat better fit $\left(R^{2}=0.994\right)$, Tempkin isotherm $\left(R^{2}=\right.$ 0.993) than the Freundlich model $\left(R^{2}=0.929\right)$ and Dubinin-Radushkevich model $\left(R^{2}=0.948\right)$. Equilibrium data fitted well with the Langmuir and Tempkin model.

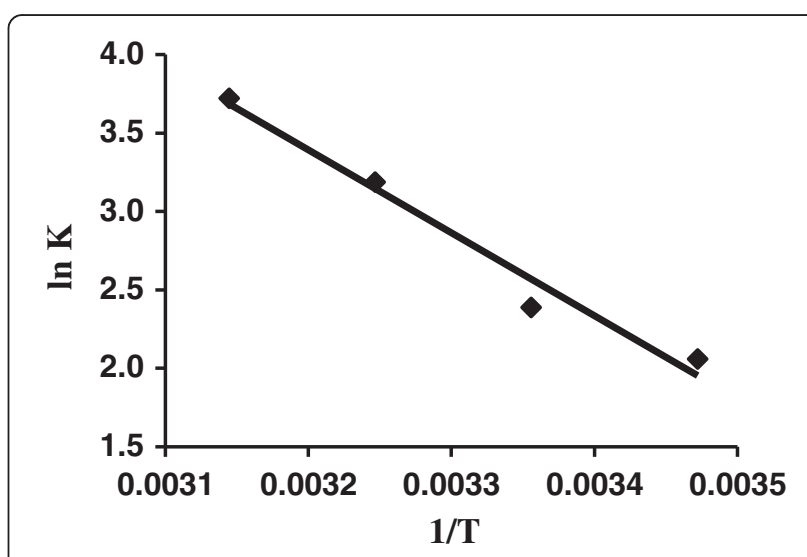

Figure 9 Van't Hoff plots for the adsorption of AB129 (40 mg/L) onto AS for evaluating thermodynamic parameters. 


\begin{tabular}{|c|c|c|c|c|c|c|}
\hline \multirow[t]{2}{*}{ Adsorbent } & \multirow[t]{2}{*}{$\mathrm{C}_{0}(\mathrm{mg} / \mathrm{L})$} & \multirow[t]{2}{*}{ Parameter } & \multicolumn{4}{|c|}{ Temperature (K) } \\
\hline & & & 288 & 298 & 308 & 318 \\
\hline \multirow{2}{*}{$\begin{array}{l}\text { Apricot } \\
\text { Stone (AS) }\end{array}$} & 40 & $\mathrm{k}_{\mathrm{c}}$ & 7.845 & 10.888 & 24.24 & 41.33 \\
\hline & & $\Delta \mathbf{G}^{\circ}(\mathrm{kj} / \mathrm{mol})$ & -4.93 & -5.91 & -8.16 & -9.83 \\
\hline$C_{0}(\mathrm{mg} / \mathrm{L})$ & & $\Delta \mathbf{S}^{\circ}(\mathrm{J} /(\mathrm{mol} \mathrm{k}))$ & & & $\Delta \mathbf{H}^{\circ}(\mathrm{kj} / \mathrm{mol})$ & \\
\hline 40 & & 168.74 & & & 43.91 & \\
\hline
\end{tabular}

\section{Thermodynamic study}

Thermodynamic parameters such as change in free energy $\left(\Delta G^{\circ}\right)(\mathrm{J} / \mathrm{mole})$, enthalpy $\left(\Delta \mathrm{H}^{\circ}\right)(\mathrm{J} / \mathrm{mole})$ and entropy $\left(\Delta S^{\circ}\right)(\mathrm{J} /(\mathrm{K}$ mole $))$ were determined using following equations

$$
\begin{aligned}
& \mathrm{K}_{\mathrm{o}}=\text { Csolid/Cliquid } \\
& \Delta \mathrm{G}=-\mathrm{RT} \ln \mathrm{K}_{\mathrm{o}} \\
& \Delta \mathrm{G}=\Delta \mathrm{H}-\mathrm{T} \Delta \mathrm{S} \\
& \ln \mathrm{K}_{\mathrm{o}}=-\Delta \mathrm{G} / \mathrm{RT} \\
& \ln \mathrm{K}_{\mathrm{o}}=\Delta \mathrm{S} / \mathrm{R}-\Delta \mathrm{H} / \mathrm{RT}
\end{aligned}
$$

Where $\mathrm{K}_{\mathrm{o}}$ is equilibrium constant, $\mathrm{C}_{\text {solid }}$ is solid phase concentration at equilibrium $(\mathrm{mg} / \mathrm{L}), \mathrm{C}_{\text {liquid }}$ is liquid phase concentration at equilibrium $(\mathrm{mg} / \mathrm{L}), \mathrm{T}$ is absolute temperature in Kelvin and $\mathrm{R}$ is gas constant. $\Delta \mathrm{G}^{\circ}$ values obtained from equation (2), $\Delta \mathrm{H}^{\circ}$ and $\Delta S$ values obtained from the slope and intercept of plot $\ln K_{o}$ against $1 / \mathrm{T}$ (Figure 9). The negative value of $\Delta G^{\circ}$ indicates the adsorption is favorable and spontaneous (Table 4). $\Delta H^{\circ}$ and $\Delta G^{\circ}$ can be obtained from the slope and intercept of Van't Hoff plot of $\ln K c$ vs. $1 / T$.

The positive values of $\Delta \mathrm{H}^{\circ}$ further confirm the endothermic nature of the adsorption process and the positive $\Delta \mathrm{S}^{\circ}$ values suggest the increase in adsorbate concentration in solid-liquid interface indicating thereby the increase in adsorbate concentration onto the solid phase. It also confirms the increased randomness at the solid-liquid interface during adsorption. This is the normal consequence of the physical adsorption phenomenon, which takes place through electrostatic interactions.

Table 5 Comparison for the removal of AB129 by different adsorbents

\begin{tabular}{llll}
\hline Adsorbent & Adsorbate & Contact time (min) & Ref \\
\hline activated carbon cloth & $\mathrm{AB} 129$ & 400 & {$[46]$} \\
Row bentonite & $\mathrm{AB} 129$ & $>1000$ & {$[47]$} \\
CTAB-bentonite & $\mathrm{AB} 129$ & $>100$ & {$[47]$} \\
Almond shell & $\mathrm{AB} 129$ & 14 & This work \\
\hline
\end{tabular}

\section{Comparison with literature}

The performance of the proposed method has been compared with other adsorbents. As is seen in Table 5 the contact time for proposed method in comparison with all of the adsorbents are preferable and superior to the literature which show satisfactory removal performance for AB129 as compared to other reported adsorbents $[46,47]$.

\section{Conclusion}

It was observed that the AS is an efficient adsorbent for the removal of AB129S. Removal of $\mathrm{AB} 129$ is $\mathrm{pH}$ dependent and the maximum removal was attained at $\mathrm{pH}=2$. The equilibrium data fitted very well in a Langmuir and Tempkin isotherm equations. The data indicate that the adsorption kinetics follow the pseudosecond-order with spontaneous and endothermic nature of the adsorption process. The positive sign of $\Delta \mathrm{S}^{\circ}$ indicates that the adsorption process takes place through electrostatic interaction between adsorbent surface and adsorbate species in solution. The present study concludes that the AS could be employed as low-cost adsorbents for the removal of AB129 from aqueous solution in general.

Competing interests

The authors declare that they have no competing interests.

\section{Authors' contributions}

All authors read and approved the final manuscript.

\section{Acknowledgements}

The authors express their appreciation to the Graduate School and Research Council of the Gachsaran Azad University for financial support of this work.

\section{Author details}

${ }^{1}$ Department of Chemistry, College of Science, Shahid Chamran University, P.O. Box: 6135743337, Ahvaz, Iran. ${ }^{2}$ Young Researchers and Elite Club, Gachsaran Branch, Islamic Azad University, Gachsaran, Iran. ${ }^{3}$ Department of Chemistry, Islamic Azad University, Gachsaran Branch, P.O. Box 75818-63875, Gachsaran, Iran. ${ }^{4}$ Young Researchers and Elite Club, Sepidan Branch, Islamic Azad University, Sepidan, Iran.

Received: 22 August 2012 Accepted: 5 March 2014

Published: 12 March 2014

\section{References}

1. Weber EJ, Wolfe NL: Kinetics studies of Kinetics studies of reduction of aromatic azo compounds in anaerobic sediment water systems. Environ Toxicol Chem 1987, 6:911-920.

2. Shivaraj R, Namasivayam C, Kardirvelu K: Peel as Orange an adsorbent in the removal of Acid violet 17 (acid dye) from aqueous solutions. Waste Manage 2001, 21:105-110.

3. Seshadri S, Bishop PL, Agha AM: Anaerobic- aerobic treatment of selected azo dyes in wastewater. Waste Manage 1994, 15:127-137.

4. Arami M, Yousefi Limaee N, Mahmoodi NM, Tabrizi NS: Removal of dyes from colored textile wastewater by orange peel adsorbent: Equilibrium and kinetic studies. J Collide interface Sci 2005, 288:371-376.

5. Reid R: Go green-a sound business decision. (Part I). J Soc Dyers Color 1996, 112:103-109.

6. Chandran $C B$, Singh D, Nigam P: Remediation of textile effluent using agricultural residues. Appl Biochem Biotechnol 2002, 102:207-212.

7. Mittal A, Jhare D, Mittal J: Adsorption of hazardous dye eosin yellow from aqueous solution onto waste material De-oiled Soya: isotherm, kinetics and bulk removal. J Mol Liq 2013, 179:133-140. 
8. Mittal A, Mittal J, Kurup L, Singh AK: Process development for the removal and recovery of hazardous dye erythrosine from wastewater by waste materials-bottom ash and de-oiled soya as adsorbents. J Hazard Mater 2006, 138:95-105.

9. Mittal A, Mittal J, Kurup L: Utilization of hen feathers for the adsorption of indigo carmine from simulated effluents. J Environ Prot Sci 2007, 1:92-100.

10. Mittal A, Mittal J, Malviya A, Gupta VK: Removal and recovery of Chrysoidine $Y$ from aqueous solutions by waste materials. J Colloid Interface Sci 2010, 344:497-507.

11. Mittal A, Gajbe V, Mittal J: Removal and recovery of hazardous triphenylmethane dye, Methyl Violet through adsorption over granulated waste materials. J Hazard Mater 2008, 150:364-375.

12. Mittal A, Kaur D, Mittal J: Batch and bulk removal of a triarylmethane dye, fast green FCF, from wastewater by adsorption over waste materials. J Hazard Mater 2009, 163:568-577.

13. Mittal A, Kaur D, Mittal J: Applicability of waste materials-bottom ash and deoiled soya-as adsorbents for the removal and recovery of a hazardous dye, brilliant green. J Colloid Interface Sci 2008, 326:8-17.

14. Mittal A, Kaur D, Malviya A, Mittal J, Gupta VK: Adsorption studies on the removal of coloring agent phenol red from wastewater using waste materials as adsorbents. J Colloid Interface Sci 2009, 337:345-354.

15. Mittal A, Mittal J, Malviya A, Kaur D, Gupta VK: Decoloration treatment of a hazardous triarylmethane dye, Light Green SF (Yellowish) by waste material adsorbents. J Colloid Interface Sci 2010, 342:518-527.

16. Mittal A, Gupta VK: Adsorptive removal and recovery of the azo dye Eriochrome Black T. Toxicol Environ Chem 2010, 92:1813-1823.

17. Mittal A: Removal of the dye, amaranth from waste water using hen feathers as potential adsorbent. Electron J Environ Agri Food Chem 2006, 5:1296-1305.

18. Mittal A, Jain R, Mittal J, Shrivastava M: Adsorptive removal of hazardous dye quinoline yellow from wastewater using coconut-husk as potential adsorbent. Fresenius Environ Bull 2010, 19:1-9.

19. Mittal A, Thakur V, Gajbe V: Evaluation of adsorption characteristics of an anionic azo dye brilliant yellow onto hen feathers in aqueous solutions. Environ Sci Pollut Res 2012, 19:2438-2447.

20. Mittal A, Jain R, Mittal J, Varshney S, Sikarwar S: Removal of yellow ME 7 GL from industrial effluent using electrochemical and adsorption techniques. Int J Environ Pollut 2010, 43:308-323.

21. Mittal A, Thakur $V$, Gajbe $V$ : Adsorptive removal of toxic azo dye amido black $10 \mathrm{~B}$ by hen feather. Environ Sci Pollut Res 2013, 20:260-269.

22. Gupta VK, Mittal A, Jhare D, Mittal J: Batch and bulk removal of hazardous colouring agent Rose Bengal by adsorption techniques using bottom ash as adsorbent. RSC Advances 2012, 2:8381-8389.

23. Robinson $T$, Chandran B, Nigam P: Removal of dyes from an artificial textile dye effluent by two agricultural waste residues, corncob and barley husk. Environment Int 2002, 28:29-33.

24. Ho YS, Chiang TH, Hsuch YM: Removal of basic dye from aqueous solutions using tree fern as a biosorbent. Process Biochem 2005, 40:119-124.

25. Nigam P, Armour G, Banat IM, Singh D, Marchant R: Physical removal of textile dyes and solid state fermentation of dye- adsorbed agricultural residues. Bioresour Technol 2002, 72:219-226.

26. Arivoli S, Kalpana K, Sudha R, Rajachandrasekar T: Comparitive study on the adsorption kinetics and thermodynamics of metal ions onto acid activated low cost carbon. E J Chem 2007, 4:238-254.

27. Renmin G, Yingzhi S, Jian C, Huijun L, Chao Y: Effect of chemical modification on dye adsorption capacity of peanut hull. Dyes Pig 2005, 67:175-181.

28. Vadivelan V, Vasnthkumar K: Equilibrium, kinetics, mechanism, and process design for the sorption of methylene blue onto rice husk. J Colloid Inter Sci 2005, 286:90-100.

29. Singh AK, Singh DP, Pandey KK, Singh VN: Wollastoniten as adsorbent for removal of Fe (II) from water. J Chem Technol 1988, 42:39-49.

30. Acharya J, Sahu JN, Sahoo BK, Mohanty CR, Meikap BC: Removal of chromium(VI) from wastewater by activated carbon developed from Tamarind wood activated with zinc chloride. Chem Eng J 2009, 150:25-39.

31. Suarez-Garcia F, Martinez-Alonso A, Tascon JMD: Activated carbon fibers from Nomex by chemical activation with phosphoric acid. Carbon 2004, 42:1419-1426.

32. Ravikumar K, Deebika B, Balu K: Decolourization of aqueous dye solutions by a novel adsorbent: application of statistical designs and surface plots for the optimization and regression analysis. J Hazard Mater 2005, 122:75-83.

33. Pavan FA, Lima EC, Dias SLP, Mazzocato AC: Methylene blue biosorption from aqueous solutions by yellow passion fruit waste. $J$ Hazard Mater 2008, 150:703-712.

34. Vaghetti JCP, Brasil JL, Costa TMH, Lima EC, Benvenutti EV: Influence of the synthesis conditions on the characteristics and metal adsorption properties of the 3-(1,4phenylenediamine)propylsilica xerogel. Eclet Quim 2005, 30:43-49.

35. Guo B, Hong L, Jiang HX: Macroporous poly(calcium acrylatedivinylbenzene) bead- a selective orthophosphate sorbent. Ind Eng Chem Res 2003, 42:5559-5567.

36. Chingombe P, Saha B, Wakeman R: Sorption of atrazine on conventional and surface modified activated carbons. J Colloid Interf Sci 2006, 302:408-416.

37. Ho YS, Mckay G: The sorption of lead (II) ions on peat. Water Res 1999, 33:578-584.

38. Langmuir $\mathrm{L}$ : The constitution and fundamental properties of solids and liquid. J Am Chem Soc 1916, 38:2221-2295.

39. Langmuir I: The adsorption of gases plane surfaces of glass, mica and platinum. J Am Chem Soc 1918, 579:1361-1403.

40. Abdelwahab O: Evaluation of the use of loofa activated carbons as potential adsorbents for aqueous solutions containing dye. Desalination 2008, 222:357-367.

41. Ng C, Losso JN, Marshall WE, Rao RM: Freundlich adsorption isotherms of agricultural by-product-based powdered activated carbons in a geosmin-water system. Bioresour Technol 2002, 85:131-135.

42. Weber JWJ: Physicalchemical Processes for Water Quality Control. New York: Wiley Interscience; 1974.

43. Haghseresht F, Lu G: Adsorption characteristics of phenolic compounds onto coal-reject-derived adsorbents. Energy Fuels 1998, 12:1100-1107.

44. Temkin MJ, Pyzhev V: Recent modifications to Langmuir isotherms. Acta Physiochim USSR 1940, 12:217-222.

45. Dubinin MM, Radushkevich LV: Equation of the characteristic curve of activated charcoal. Chem Zentr 1947, 1:875-890.

46. Hoda N, Bayram E, Ayranci E: Kinetic and equilibrium studies on the removal of acid dyes from aqueous solutions by adsorption onto activated carbon cloth. J Hazard Mater 2006, 137:344-351.

47. Yesi Sisnandy FP, Ju YH, Soetaredjo FE, Ismadji S: Adsorption of acid blue 129 from aqueous solutions onto raw and surfactant-modified bentonite: application of temperature-dependent forms of adsorption isotherms. Adsorpt Sci Technol 2010, 28:847-867.

\section{doi:10.1186/2052-336X-12-62}

Cite this article as: Fat'hi et al:: Kinetics and thermodynamic studies for removal of acid blue 129 from aqueous solution by almond shell. Journal of Environmental Health Science \& Engineering 2014 12:62.

\section{Submit your next manuscript to BioMed Central and take full advantage of:}

- Convenient online submission

- Thorough peer review

- No space constraints or color figure charges

- Immediate publication on acceptance

- Inclusion in PubMed, CAS, Scopus and Google Scholar

- Research which is freely available for redistribution 